Journal of Health Policy and Management (2017), 2(2): 128-136

https://doi.org/10.26911/thejhpm.2017.02.02.04

\title{
The Role of Community Health Workers in Maternal and Child Health Surveillance to Optimize Maternal and Child Health in Pasuruan District, East Java
}

\author{
Ninil Dwi Pangestu'), Hermanu Joebagio²), Setyo Sri Rahardjo3) \\ ${ }^{1)}$ Masters Program in Public Health, Universitas Sebelas Maret, Surakarta \\ 2)Faculty of Teaching and Educational Sciences, Universitas Sebelas Maret, Surakarta \\ 3) Faculty of Medicine, Universitas Sebelas Maret, Surakarta
}

\begin{abstract}
Background: Maternal mortality ratio, infant mortality rate, and underfive mortality rate are still high in Indonesia. Pasuruan is one of the districts in East Java with the highest infant mortality rate. One of the public health interventions that has been undertaken to address this issue is maternal and child health surveillance program with community health workers being the leading implementers. This study aimed to describe the role of community health workers in maternal and child health surveillance to optimize maternal and child health care services in Pasuruan District, East Java.

Subjects and Method: This was a qualitative study using case study approach. It was conducted in Pasuruan, East Java. Key informants were selected by criterion sampling. The data were collected by in-depth interview, focus group discussion, observation, and document review. Data validity was checked by triangulation.

Results: Community based maternal and child health surveillance program has been implemented for 4 years. However, only some of all community health workes have been trained in this program. The tasks of these community health workers included advocacy and monitoring of maternal and child health in the areas of posyandu. The implementation of these surveillance program had some obstacles, including low insentive of community health worker, inactive community health worker, lack of awareness among community members on maternal and child health issues, and medical factors of pregnant mothers that caused mortality.

Conclusion: Community health workers help improve the quality of maternal and child health care by surveillance program, although their performances have yet to be enhanced.
\end{abstract}

Keywords: maternal mortality rate, infant mortality rate, community health workers

\section{Correspondence:}

Ninil Dwi Pangestu. Masters Program in Public Health, Sebelas Maret University, Jl. Ir. Sutami No.36A Surakarta 57126, Jawa Tengah. Email: pangestu.ninil@gmail.com. Mobile +62856553737.

\section{BACKGROUND}

Maternal and child mortality become a serious problem for some states especially for developing country. Indonesia is one of developing countries with low maternal and child health status. Indonesia's Maternal Mortality Rate (MMR) was 359 per 100,000 live births, Infant Mortality Rate (IMR) was 32 per 1,000 live births, and Under-five Mortality Rate (UMR) was 40 per 1000 live births as (Health Ministry, 2015).
Indonesia ranks seventh of eleven countries in South East Asia with the Maternal Mortality Rate is 126 per 100,000 live births in 2015 (WHO, 2015). This high Maternal Mortality Rate is supported by some districts in Indonesia which experience the increasing of Maternal and child mortality. Those districts are North Sumatra, Banten, West Java, Central Java, East Java, South Sulawesi (Health Ministry), 2015).

This high Maternal and Child Mortality Rate brings Indonesia for losing the tar- 
get which is signed by Millennium Development Goals (MDGs) in the end of 2015. MDGs set the target for Indonesia to reduce the Maternal Mortality Rate into 102 per 100,000 live births, Infant Mortality Rate into 23 per 1000 live births, Under-five Mortality Rate into 32 per 1,00o live births.

The high Maternal and Child Mortality indicates a country's general health status is still low. Maternal and Child Health is the way to improve general health status of the community as an investment for nationnal development. The Law No. 36 clause 126/ 2009 states the effort for Maternal Health is addressing to keep the Maternal health in order to give birth a healthy and qualified generation as well to decrease the Maternal Mortality Rate.

This incidence requires the government to work harder to decrease the Maternal and Child Mortality. The target of Maternal Mortality Rate in Indonesia is must decrease to 306 per 100,00o live births and the Infant Mortality Rate to 24 per 1,000 live births in the end of 2019. However, to reach that goal it requires the collaboration effort among Central Government, Local Government, Cross Sector and the community (Health Ministry, 2015).

Health sector decentralization requires the Local Government to innovate the health program policy. Maternal and Child Health program is one of the programs in Indonesia, innovation in health program is required to accelerate the reduction of $\mathrm{Ma}$ ternal Mortality Rate and Infant mortality Rate in each area of Indonesia. District in Indonesia who has the innovation on Maternal and Child Health program policy by making Local Regulation Area are Pasuruan district in East Java, Takalar District in South East Sulawesi and Kupang District in East Nusa Tenggara (Nurrizka and Saputra, 2013).
Pasuruan district is one of districts in East Java with the highest Infant Mortality Rate (Central Bureau of Statistic of East Java 2014).

Figure 1. Infant mortality rate in East Java

\begin{tabular}{cccc}
\hline Year & MMR & IMR & UMR \\
\hline 2011 & 22 & 157 & 28 \\
2012 & 27 & 236 & 23 \\
2013 & 28 & 206 & 92 \\
2014 & 28 & 298 & 68 \\
2015 & 26 & 198 & 68 \\
2016 & 23 & 171 & 15 \\
\hline
\end{tabular}

Source: District Health Offices Pasuruan, 2016.

The towering MMR, IMR, and UMR require the Regional Government of Pasuruan District to make regional regulation by means of Regent's Decision No. 440/ 749/HK/240.013/2013 which states that the Government of Pasuruan District is obligated to protect its entire population in actualizing general health status of the community by means of establishing Community Health Workers with the area of Posyandu. Community Health Workers are health workers who are engaged to give assistance and monitoring toward the assigned health target within a posyandu area (Pasuruan District Health Offices, 2013).

The community health worker is part of the community empowerment to increase the health level involving the community participation. The community health worker is an innovative program made by Ngempit community healthcare centre (Puskesmas) in 2009. Based on the evaluation made by Pasuruan District Health Offices, The community health worker is able to reduce the MMR and IMR, improving the examination of pregnant women coverage, improving the early detection on the high risk pregnant women coverage, improving the community participation in community 
Journal of Health Policy and Management (2017), 2(2): 128-136

https://doi.org/10.26911/thejhpm.2017.02.02.04

health centre, improving the early detection on child growth in Ngempit Puskesmas. The success of this program inflicted Pasuruan District Health Offices in 2013 to implement the community health worker program in all puskesmas in Pasuruan District.

This study aimed to describe the role of community health workers by means of $\mathrm{MCH}$ surveillance to optimize maternal and child health in Pasuruan district.

\section{SUBJECTS AND METHODE}

This was a qualitative descriptive study with case study approach. The study was conducted in Pasuruan District which was located in Klampis Rejo Posyandu in the area of Ngempit Puskesmas, and Polokarto Posyandu in the area of Kraton Puskesmas. Data collection was conducted in September until October 2017.

The sampling technique used was purposive sampling. The key informant of the study was Public Health Promotion Division of Pasuruan District Health Office. The main informants were community health workers, midwives coordinator, and village midwives. The supporting informant was community.

The data were collected by using indepth interview, focus group discussion, observation, and document analysis. Data collection instruments used in the study were interview guidelines, voice recorder, camera, documents needed in the study, and observation forms.

\section{RESULTS \\ 1. The role of community health wor- kers in maternal and child health surveillance}

Based on the interview and FGD it concluded that the community health workers conducted the surveillance to update data or information about the health of his/ her clients. It was carried out by doing observa- tion during posyandu activities, home visit, and daily interactions. The results were recorded on the community health workers' register book, which consisted of infant and under-five register, pregnant women register, high risk pregnant women monitoring register, and head of family register. In which there was an issue of maternal and child health such as high risk pregnant women, infant with incomplete immunization, infant and under-five with nutrition disorder it required intensive assistance and monitoring.

\section{The role of community health wor- kers in reducing MMR, IMR, and UMR}

All this time the community health workers helped in the reduction of MMR, IMR, and UMR. The role of the community health workers to reduce the Mortality rate is by making an early detection on pregnant women and infant and under-five growth; monitoring maternal and child health; reporting to village midwives if there were mother, infant and under-five with health problem in order to get immediate and appropriate treatment.

The escalating mortality rate was not only caused by the factor of community health workers but also there were other cause namely medical factor such as illness suffered by mothers and lack of public awareness on maternal, infant and child health. Therefore the high maternal, infant and child mortality were not only caused by the absent-minded of community health workers in carrying out their roles.

\section{The role of the community health workers in increasing the coverage of early pregnancy detection, and pregnancy monitoring}

Based on the interview and FGD it concluded that the role of the community health workers helped to increases the coverage of pregnancy examination. Yet, pregnan- 
cy examination coverage did not achieve its $100 \%$ target assigned, in particular $\mathrm{K}_{4}$ frequently did not reach $100 \%$.

All this time, the community health workers contributed to help in increasing coverage of pregnancy examination by checking $\mathrm{MCH}$ book to ensure that pregnant women regularly visited health worker for antenatal care. The community health workers also contributed to give assistance to the pregnant women, did the home visit if the pregnant women did not yet received antenatal care, providing motivation and information about pregnancy.

The role of the community health workers in early pregnancy detection was by conducting assessment on the risk level of pregnant women by using Poedji Rochjati score, unfortunately not all of the community health workers were able to use the Poedji Rochjati score therefore it needed assistance of local midwives in conducting early pregnancy detection.

The community health workers conducted monitoring on pregnant women during the posyandu activities, home visit, and daily interaction. The monitoring activity was conducted in various frequency sometimes it was once a month along with with the monitoring of mosquito larva, some others were conducted once in three months.

The role of the community health workers in pregnancy monitoring is to ensure the pregnant women had routine antenatal care by health workers, ensure they underwent USG examination and albumin test, observe the condition of pregnant women to identify maternal and fetal health condition, conducted home visit for checking the pregnant women condition at home, report to the midwives if a pregnancy emergency occurred.

\section{The role of the community health workers in increasing the posyan- du participation and early child growth detection}

Based on the interview and FGD it concluded that posyandu has experienced the increased participation but did not yet attain the targeted $85 \%$. Community health workers played a role in increasing posyandu participation by giving information about the schedule of posyandu to each client through the mosque's loudspeaker, slit drum, notification letters, recitation, and home visit; clients who did not come to posyandu would be visited by the community health worker, while the child who did not showed up for immunization would also be visited by the community health workers and the midwives to get the immunization at home.

The role of the community health workers in early detection of growth and development was conducting assessment on the growth and development of infant and under-five by using Growth Chart. Moreover, community health workers also used development indicators as detection of under-five's motor development. However, not all posyandu held early detection on under-five growth and development.

\section{$\frac{\text { DISCUSSION }}{\text { 1. The role of the community health }}$ workers through Maternal and Child Health Surveillance}

Observation and data collection by community health workers still faced obstacles in the implementation. It was found that the community health worker was not active in filling out the book of community health worker because of illiteracy so the data collection was not running well. These obstacles in data collection showed that the community health workers in Pasuruan district did not fully utilize the book of com- 
Journal of Health Policy and Management (2017), 2(2): 128-136

https://doi.org/10.26911/thejhpm.2017.02.02.04

munity health worker (Alyyuddin, 2017). The fact happened because not all people are willing to voluntarily become community health worker.

Community health workers received incentive Rp 150,000 once in 6 months for carrying out tasks, not only conducted observation on maternal and child health but also helped the environmental health improvement. The incentive was not proportional with the work load therefore this lack of intensive was a factor that influences the community health workers' motivation to play their role. It is supported by a study (Yanti dan Hasballah, 2016). Incentive factor also impacts the observation activity through home visit by the community health worker. Home visit was situational however some community health workers did in once a month, once in 3 months or in uncertain time. This case was not in line with the relevant study by Perez, et al (2009) which states that home visit gives positive impact to family healthcare therefore home visit observation by the community health worker is required.

The less optimal observation and data collection by community health workers resulted in the lack of monitoring on maternal and child health in which impacted to less issues which were handled. This finding was supported by the Alyyuddin study (2017) which stated that community health workers in Pasuruan handled the issues well by $41.8 \%$, this result showed that more community health workers did not handle issue. Therefore, the observation and data collection by community health workers are very important to identify the maternal and child issues that a special monitoring can be conducted in order to provide an effective handling.

\section{The role of community health wor- kers in reducing MMR, IMR, and UMR}

Maternal Mortality Rate and Infant Mortality Rate in Pasuruan district declined in 2015. It was helped by some health programs in Pasuruan district, one of them was the community health worker program. Community health workers helped to optimize the community participation in improving general health status. One of the activities to improve general health status was by improving the quality of maternal and child health through posyandu activity. Posyandu activity helps community health workers to conduct the early detection in illness prevention of pregnant women, breastfeeding mothers, childbed mothers, under-five and couple in reproductive age (Noerjoedianto et al., 2014). Posyandu activity also helps community health workers in monitoring maternal and child health which is the part of their responsibility.

During the implementation in community health workers' activities, there were some community health workers who were inactive by not participating in posyandu activity. It generated the lack of monitoring on maternal and child health, and lead to the tardiness in problem identifycation and emergency management that might result in death. Community health workers as the partner of health personnel are supposed to help Government in reducing maternal, infant and under-five mortality rate since the government cannot overcome this problem without community participation (Chasanah, 2015). This community based strategy results in bigger intervention coverage than healthcare facility based thus the community health workers' role is very important to help the government improving the maternal and child health as the effort to reduce MMR, IMR, and UMR in Indonesia (Haver et al., 2015). 
Furthermore, the issue of high MMR, IMR, UMR are not fully caused by community health workers instead it may be caused by the medical factors of the mother such as pregnant women with Tuberculosis, heart disease that might disturb maternal and fetal health. Another issue found was that there were pregnant women who had antenatal care and gave birth in traditional midwives despite the community health workers' assistance and suggestion to have antenatal care and give birth assisted by health personnel. This shows mother's lack of awareness which is influenced by insufficient knowledge on health. The low mother's knowledge on health will influence the decision toward labor assistant, it is parallel to Karjono et al. (2013) which stated that mother's knowledge is a dominant factor in making the decision for labor assistance. This result of study is corresponding to a relevant study by Pranata et al. (2011) which explained that community health workers is not yet able to help society to immediately make decision in shifting health behavior.

\section{The role of community health wor- kers in improving antenatal care coverage, early detection and preg- nancy monitoring}

Home visit by community health workers could be beneficial to identify any pregnant women who did not yet have and did not want to have antenatal care thus home visit was assumed as the way to help improving antenatal care (Lema et al., 2014). This case was irrelevant with the fact in the field that not all community health workers conducted home visit to each client to monitor pregnant women and ensure pregnant women had antenatal care with health personnel.

This issue was supported by Pasuruan district health office data of 2016, which showed that the coverage of pregnancy exa- mination with $\mathrm{K}_{1}$ was $101.10 \%$ and $\mathrm{K}_{4}$ was 91.63\% meanwhile $K_{1}$ and $K_{4}$ target coverage was $100 \% . K_{4}$ coverage in Pasuruan district had not reach the target yet though antenatal care was one of the efforts in reducing maternal mortality rate and infant mortality rate through pregnancy complication detection. All pregnant women were expected to obtain antenatal care from health personnel since most of maternal mortality are caused by pregnancy, labor and puerperium complication. Pregnancy complication may threaten life, but some can be be prevented by early detection in order to get immediate and appropriate medical aids (Hidayah et al., 2016).

Unachieved target of antenatal care coverage explains that there are problems that hinder the accomplishment of antenatal care coverage as stated by a study conducted by Fitrayeni et al. (2015) in which incomplete ANC examination undergone by pregnant women were influenced by low knowledge, negative attitude and unsupporting family (husband). Furthermore there was a pregnant woman who refused to join pregnancy class despite being informed by her community health worker. Pregnancy class program was actually an important activity in improving the knowledge, modify attitude and behavior to understand pregnancy, childbirth, puerperium period, post partum contraception as it is explained by a study by Setyaningsih et al. (2016) in which it stated that the existence of pregnancy class program may improve the pregnant women's knowledge.

Another issue found was that community health workers who were not yet able to carry out early pregnancy detection by using Poedji Rochjati score to detect the pregnancy risk factors that might lead to emergency. This fact may happen because each community health worker has different capability to receive information which 
Journal of Health Policy and Management (2017), 2(2): 128-136

https://doi.org/10.26911/thejhpm.2017.02.02.04

influences the information delivery and implementation so it is important for the community health worker to be accompanied by midwives during early pregnancy detection.

\section{The Posyandu and early detection of growth and development}

All this time community health workers were able to help improving the community's participation in posyandu activity however, the effort conducted by the community health workers were not yet followed by the whole community. It was in accordance with the data of Pasuruan District Health Office that the community participation had not reach the $85 \%$ target yet. There were factors found that caused community did not participate in posyandu activity. It was the lack of awareness toward the importance of posyandu. One of posyandu activities is to identify the growth and development of infant and under-five children.

It is in accordance with a study of Wilianarti et al. (2016) which stated that the determinant factor of under-five mothers' participation in posyandu activity was lack of knowledge, attitude, accessibility, and financial problem. In addition, there were community health workers who did not conduct early detection of under-five growth and development. It was generated by community health workers' lack of knowledge toward the importance of early detection on growth and development as it was stated by Aticeh and Maryanah (2015) who stated that maternal age, education, and knowledge influenced the community health workers' motivation toward the implementation of early detection on children's growth and development. In fact, early detection is one of the efforts to get a qualified child through monitoring of under-five's growth and development by implementing early growth and development stimulation. This activity was an effort to know child's development as early as possible, therefore the community health workers played an important role in improving posyandu participation and conducting early detection on child growth and development.

Based on the study result, it is concluded that the observation and data collection by community health workers faces some obstacles because they do not fill out the book of community health workers and the insufficient observation which leads to the less optimum maternal and child health monitoring.

The role of community health workers were not optimal in reducing the maternal mortality rate, infant mortality rate and under-five mortality rate however the in the implementation it found several issues such as community health workers who did not come to the posyandu, pregnant women's lack of awareness to obtain antenatal care from and childbirth with health personnel. The community health workers were not able to encourage the community to have healthy living lifestyle.

The role of community health workers help to improve the coverage of antenatal care and pregnancy monitoring as well as early detection. However the role of community health workers are not yet optimal because there are mothers who did not obtain their antenatal care from health personnel, there are mothers who do not attend pregnancy class, community health workers who do not conduct early detection by using Poedji Rochjati score.

The community health workers help in improving posyandu participation however the contribution is not yet optimum because there are some of the community who do not participate in posyandu activity and not all workers conduct early detection on under-five growth and development. 


\section{REFERENCE}

Alyyuddin M (2017). Evaluasi pelaksanaan program kader asuh di kabupaten pasuruan (Evaluation of the implementation of cadre program in Pasuruan district). Jurnal Ilmu Kesehatan 3 (1): 36-44. Retrieved from https://stikvinc.ac.id/jurnal/index.php/jpk/article/v iew/148

Aticeh, Maryaticeanah SS (2015). Pengetahuan kader meningkatkan motivasi dalam melakukan deteksi dini tumbuh kembang balita (Cadre knowledge increases motivation in conducting early detection of children's growth). Jurnal Ilmu dan Teknologi Kesehatan, 2(2): 71-76. Retrieved from https://adoc.tips/download/pengetahuan-kader-meningkatkan-motivasi-dalammelakukan-dete.html

Central Bureau of Statistic of East Java (2014). Angka Kematian Bayi. Retrieved from https://jatim.bps.go.id/statictable/2015/02/o6/151/angka-kematian-bayi-akb-penduduk-jawa-timurmenurut-kabupaten-kota-2009-2014.html

Chasanah SU (2015). Peran petugas kesehatan masyarakat dalam upaya penurunan angka kematian ibu pasca MDGs (The role of public health officers in the efforts to decrease maternal mortality rate of MDGs). Kesehatan Masyarakat Andalas, 9(2): 73-79. Retrieved from http://jurnal.fkm.unand.ac.id/index.php/jkma/article/view /190

Pasuruan District Health Offices (2013). Petunjuk teknis program kader asuh (Technical guidelines for cadre programs). Pasuruan: Dinas Kesehatan Kabupaten Pasuruan. Retrieved from https://dinkes.pasuruankab.go.id/berita-program-kader-asuh-2014.html

Dwi N, Andy A, Nurhusna H (2014). Kata kunci: kegiatan posyandu, peran aktif kader, kegiatan terintegrasi (Key words: Posyandu activities, active role cadres, integrated activities). Jurnal Pengabdian Masyarakat, 29(4): 4353. Retrieved from https://online-journal.unja.ac.id/jlpm/article/view/24 $68 / 1781$

Fitrayeni, Suryati, Faranti RM (2015). Penyebab rendahnya kelengkapan kunjungan antenatal care ibu hamil di wilayah kerja puskesmas pegambiran (Causes of low antenatal care visit to pregnant women in the working area of the Community Health center of Pegambiran), 10(1): 101-107. Retrieved from http://jurnal.fkm.unand.ac.id/index.php/jkma/article/view/170

Haver J, Brieger W, Zoungrana J, Ansari N, Kagoma J (2015). Experiences engaging community health workers to provide maternal and newborn health services: Implementation of four programs. International Journal of Gynecology and Obstetrics. Elsevier BV. 130(S2): S32-S39. doi: 10.1016/j.ijgo. 2015. 03. 006.

Hidayah L, Handayani OID (2016). Public health perspective. Public Health Perspective Journal, 1(1): 36-43. Retrieved from https://journal.unnes.ac.id/nju/index.php/phpj/article/do wnload/7754/5398

Karjono M, Wulandari LPL, Suryadhi NT (2013). Pengetahuan sebagai determinan dalam pengambilan keputusan penolong persalinan ibu hamil di Puskesmas Taliwang tahun 2013 (Knowledge as a determinant in the decision to make maternity helper in Taliwang health center 2013). 1(1): 63-69. Retrieved from httpswww.neliti.com/publications/21522/pengetah uan-sebagai-determinan-dalam-pengambilan-keputusan-penolong-persalinan-i 
Journal of Health Policy and Management (2017), 2(2): 128-136

https://doi.org/10.26911/thejhpm.2017.02.02.04

Kementerian Kesehatan (2015). Profil Kesehatan Indonesia 2014 (Health Profile of Indonesia 2014). doi: 10.1037/0022-3514. 51.6.1173.

Lema IA, Sando D, Magesa L, Machumi L, Mungure S, Sando MM, Geldsetzer P, et al (2014). Community health workers to improve antenatal care and PMTCT uptake in Dar es Salaam, Tanzania: A quantitative performance evaluation. Journal of acquired immune deficiency syndromes (1999). 67(4): S195-201. doi: 10.1097/QAI.sooooooooooooo37.

Nurrizka RH, Saputra W (2013). Arah dan strategi kebijakan penurunan angka kematian ibu (AKI), angka kematian bayi (AKB) dan angka kematian balita (AKABA) di Indonesia (The direction and strategy of policy reduction of maternal mortality (AKI), infant mortality rate (AKB) and infant mortality rate (AKABA) in Indonesia). Retrieved from https://www.neliti.com/publications/671/arah-dan-strategi-kebijakan-penurunan-angka-kematianibu-aki-angka-kematian-bayi

Perez F, Ba H, Dastagire SG, Altman M (2009). The role of community health workers in improving child health programmes in Mali. BMC International Health and Human Rights, 9(1): 28. doi: 10.1186/1472-698X-9-28.

Pranata S, Pratiwi NL, Rahanto S (2011). Pemberdayaan masyarakat di bidang kesehatan: gambaran peran kader posyandu dalam upaya penurunan angka kematian ibu dan bayi di kota manado dan palangkaraya (Commu-

nity empowerment in the field of health: the role of Posyandu cadres in the efforts to decrease maternal and infant mortality in Manado and Palangkaraya cities). 14(2): 174-182. Retrieved from http://ejournal.litbang.depkes.go.id/index.php/hsr/arti cle/view/2321

Setyaningsih R, Adriyani PUM (2016). Kehamilan di Kabupaten Banyumas (Pregnancy in Banyumas District). Jurnal Pengabdian Kepada Masyarakat, 22(3): 135-139. Retrieved from https://jurnal.unimed.ac.id/2012/ind ex.php/jpkm/article/view/4780

Wilianarti PF, Aryunani, Sumarliyah E (2016). Determinan faktor partisipasi ibu balita dalam kegiatan posyandu di Desa Kejawan Putih, Tambak, Kecamatan Mulyorejo (Determinant of participation factor of toddler mother in Posyandu activity in Kejawan White village, Tambak, Mulyorejo District), 1(1): 15-22. Retrieved from http://journal.um-surabaya.ac.id/index.php/Axiologiya/article/view/302

World Health Organization (2015). Maternal Mortality Data Base in World. http://www.who.int/gho/maternal_h ealth/mortality/maternal/en/.

Yanti SV, Hasballah K (2016). Studi komparatif kinerja kader posyandu wilayah kerja Puskesmas Blang Bintang (Comparative study of the performance of Posyandu Kader working Area Public Health Center Blang Bintang), 4(2): 1-11. Retrieved from http://www.jurnal.unsyiah.ac.id/JIK/arti cle/download/6078/5008 